\title{
Education of Ho Chi Minh's Moral Example for Students in Vietnam Nowadays
}

\author{
Master. Nguyen Thi Khuyen \\ Department of Political Theory, Tay Nguyen University, 567 Le Duan, \\ Buon Ma Thuot City, Dak Lak, Vietnam
}

\begin{abstract}
Ho Chi Minh was one of the thinkers and revolutionary activists who had special interest in morality. In anywhere or at any time, Ho Chi Minh always first spoke and wrote about morality. More importantly, Ho Chi Minh always acted and behaved in accordance with moral standards that he set. Ho Chi Minh not only left a moral ideological system but also an example of the moral standards that he raised. Ho Chi Minh's thought and moral example were not only of great value to revolutionary work of national liberation but in the current period of national development, becoming a solid spiritual foundation of life in Vietnamese society.

Vietnamese students are educated youth, a source of high quality labor of society, is generation that continues the legacy of ancestor's revolution. In order to do that, to promote the strength of Vietnamese youth in the work of building and defending the country requires the family, school and society to take care of them and educate them and the formation of revolutionary moral characteristics for students is determined to be fundamental. Ho Chi Minh was the pure embodiment, the most typical of the pure and beautiful moral qualities; therefore, education of Ho Chi Minh's moral example becomes a matter of necessity. In this article, the author focuses on clarifying basic issues, namely: the concept of students and the education of Ho Chi Minh's moral example for students; Ho Chi Minh's moral example and contents of Ho Chi Minh's moral example needed to educate Vietnamese students nowadays.
\end{abstract}

Keywords: education, normal example, Vietnam

DOI: $10.7176 /$ RHSS/10-4-12

Publication date: February $29^{\text {th }} 2020$

\section{BEGINNING}

The morality initiated by Ho Chi Minh contained beautiful, eternal and high values that advanced human beings are aiming at, the true, the good and the beautiful. Most importantly, Ho Chi Minh's life is a model for those values. For Ho Chi Minh, morality is a practice not abstract theory, taking efficiency as a measure. Ho Chi Minh always set an example in daily life and revolutionary activities to make the right, the good and the thue were more flourishing and the wrong, the bad, the evil were increasingly lost. This made Ho Chi Minh's life a great morality book and made Ho Chi Minh's morality an intense vitality, pervasive, stirring, strong attraction not only to the Vietnamese but also to international friends, not only to their contemporaries but also to people of later generations.

\section{HISTORY OF SUBJECT RESEARCH}

There have been many dometic and international scientists researching about Ho Chi Minh's moral example. In addition, scientists and educators also have many studies on Ho Chi Minh's moral education for students of colleges and universities in Vietnam today. Here are the most outstanding works that the author has inherited and developed in her article

Author Thanh Duy in "Ho Chi Minh Thought on Morality" affirmed, Ho Chi Minh first approached and exploited the value of traditional moral thought, traditional Vietnamese morality. Along with the values of national traditions, Confucianism had a certain influence on Ho Chi Minh's moral thought but Ho Chi Minh has created his own system of moral ideas, revolutionary morality. Because when coming to Marxism - Leninism, Ho Chi Minh not only learned the method of dialectical work but also applied it as a method of moral cultivation. The author pointed out the role of Ho Chi Minh's morality and moral thought on the victory of the Vietnamese revolution. Ho Chi Minh's morality with the organic connection between Ho Chi Minh's thought and moral example whose core content are the true, the good and the beautiful becomes a valuable heritage to help the generation of tomorrow overcome difficulties. Therefore, it is necessary to exploit Ho Chi Minh's moral heritage and example from now on to ensure that the moral and social ideological foundation would not be deviated. Thus, in this work, the author clarified the origin, the role of Ho Chi Minh's thought and moral example, and affirmed the necessity of exploiting that great and valuable spiritual heritage.

"Following Uncle Ho's moral example" collected and compiled by Manh Ha. The book consists of two parts, Part I "Following Uncle Ho's moral example", the author clarifies the main contents of Ho Chi Minh's thought and moral example, the contents of learning and following the thought, Ho Chi Minh's moral example in the current period. In Part II, the author collects stories about Ho Chi Minh's moral example. Those are heartwarming, true 
stories told by people who have met and defended Ho Chi Minh. Thereby helping readers feel very clearly the immense love from Ho Chi Minh to teenagers, the caring care for, caring for the soldiers, the care for the lives of all classes of people, vivid expression of the revolutionary moral standards: loyal to the country, filial piety to the people, need, thrifty, integrity, righteousness, impartiality, ... through the life of revolutionary activities and through daily life of Ho Chi Minh. In the book, the author generalizes the main contents of Ho Chi Minh's moral thought and example, from which, refines the contents to be learned and followed through stories about Ho Chi Minh's moral example that are collected by the author.

According to author Song Thanh in "Uncle Ho - a shining example of morality", Ho Chi Minh's moral example was example of a great man who had gone beyond the national domain, becoming an example that many people admire and follow. The starting point of that example is the ideal of leading the wholel life struggling for national interests and people's well-being of Ho Chi Minh. The highlight of Ho Chi Minh's moral example that the author focuses on is that it is frugal, simple, disdain for luxury, pure personal life and extraordinary humility. Ho Chi Minh's morality is also a virtue of kindness, altruism, tolerance, kindness. Ho Chi Minh devoted "endless love" to comrades and compatriots. In that love, there was space for everyone, not forgetting, not missing anyone. With this research, the author has clarified the basic content of Ho Chi Minh's moral example, that is: to strive for the whole life for the Fatherland and for the people; frugal, homely, humble, pure private life; love, selflessness, tolerance, kindness.

"Uncle Ho's morality is a mirror for all generations" by Tran Viet Hoan. The author portrays Ho Chi Minh's example with high moral qualities. According to the author, Ho Chi Minh - a person for great benefit of the nation. Every victory of our nation in the last few decades as well as every change in each Vietnamese: from the bowl of rice, the clothes, the right to life and the right to own of every citizen; Vietnam's independence, freedom and position in the international platform today are all associated with the name and career of Ho Chi Minh. Because all enthusiasm and life of Ho Chi Minh associated with the destiny of the nation, the fate of every citizen. From the observation and contemplation of Ho Chi Minh's moral example, the author has drawn profound lessons in Ho Chi Minh that every Vietnamese citizen needs and can learn and practice; those are: loyalty to the country; for the people, love people; for the citizen, to respect and set an example, live modestly, simply and economically; saying must be accompanied with practice,...

"Educating Ho Chi Minh's morality for students of universities and colleges in teaching Ho Chi Minh Thoughts" by Le Thi Van Anh. According to the author, Ho Chi Minh's moral education for students is the process of influencing educational subject through his moral thoughts and examples to shape in them their moral sense, affection, belief, and reason and is expressed in moral behavior. The content of Ho Chi Minh moral education for students is very diverse, including: educating about the position, the importance of morality for each person; education the quality of loyalty to the country, filial piety to the people; education of the noble qualities hardworking, economical, honesty, righteous; educating human love; require students to educate themselves and train themselves against individualism; educating students of international spirit of purity; educating Ho Chi Minh's moral example. Based on the practical survey in the Northwest region, the author has proposed requirements and measures to educate Ho Chi Minh's morality for university and college students in teaching Ho Chi Minh Thought subjects. Thus, in this book, the author has analyzed and clarified the concept and content of Ho Chi Minh's moral education for students, and at the same time proposed requirements and measures for Ho Chi Minh's moral education for students of universities and colleges in teaching Ho Chi Minh Thought subject.

\section{CONTENT}

\subsection{Concept of student and educating Ho Chi Minh's moral example for Vietnamese students nowaday 3.1.1. Concept of student}

Student is a Latin term "Studens", English term is "Student", used to refer to those who are studying at universities and colleges, most of them are aged from 18 to 25 . Students are educated young people sensitive to the new, dynamic, eager to learn, explore and create, and becoming main reserve for intellectuals. The Communist Party of Vietnam and the State of Vietnam always identify students as one of the important forces that inherit and promote revolutionary achievements of the Communist Party of Vietnam, of the nation, and always take the lead in building and defending the Fatherland. In particular, in current knowledge economy, when the intellect becomes the nation's largest resource, intellectual team plays the most important resource; the Communist Party of Vietnam, the State of Vietnam pays more attention, care and fostering generations of students to become the future owners of the country.

In recent years, promoting historical tradition, Vietnamese student force has constantly strived, made many achievements in learning, scientific research, and cultivated revolutionary morality. In academic research and studying, many students are smart, industrious, creative, and strive to embrace scientific knowledge, become good experts, and strive to train their political power, morality and lifestyle.

\subsubsection{Concept of education Ho Chi Minh's moral example to students}

Moral education for students is the process of influencing students with ethical knowledge, organizing practical 
activities, and following moral examples in order to formulate ethical standards, values, beliefs that are expressed by students' behaviors and lifestyles. During this process, through moral examples, real people with action, real work used by educational subject is considered the most effective way of education.

Therefore, educating Ho Chi Minh's moral example for students is the process of educational subjects in universities such as teaching staff, officials of socio-political organizations such as Youth Union, Association Students with different contents, forms, methods and means impacting on students in order to form their knowledge, feelings and beliefs and inspire them to act and behave according to moral example of Ho Chi Minh

\subsection{Ho Chi Minh's moral example and contents of Ho Chi Minh's moral example needed in teaching Vietnamese students nowadays. \\ 3.2.1. Ho Chi Minh's moral example}

In the history of nation, Vietnamese people always worship the examples of national heroes, great cultural people, people who have contributed to the country and the people. These examples have great educational value for the following generations. The morality and personality of these historical figures became the moral standards and values of society, from generation to generation still transmitting moral lessons about them. Not only leaving a system of views on revolutionary morality, Ho Chi Minh also left behind the practice of moral life, a model of revolutionary moral practice, and an example of morality.

Ho Chi Minh's moral example is whole consistent, complete and typical representation of revolutionary moral standards through activities, behaviors and lifestyles in relationships with people, with daily communication and behavior of Ho Chi Minh

\subsubsection{Contents of Ho Chi Minh's moral example needed in teaching Vietnamese students nowadays}

Moral example of Ho Chi Minh formed during the life of its revolutionary activities and crystallized fine traditional values of Vietnamese nation, converging the essence of human morality with those basic contents that are the love of patriotism, love the people; hardworking, economical, honesty, righteousness, simple, tolerant.

Example of patriotism love, people love of Ho Chi Minh

In the early twentieth century, feeling sorry for the suffering of his compatriots, Ho Chi Minh went abroad to see how he could return to help their country and compatriots. Journey to find a way to save the country lasted 30 years, Ho Chi Minh traveled through many different countries throughout the oceans and continents with many different names, pseudonyms, aliases. Ho Chi Minh also did all kinds of jobs, hard labor, hard work to live, through countless hardships and dangers to complete the career that he pursued. Ho Chi Minh once said: "My whole life has only one purpose, is to strive for the interests of the Fatherland and the happiness of the people. Whenever I have to hide in the mountains, or out in prison, incite the danger - is for that purpose ... Anytime, anywhere, I just pursue one purpose, bring benefit the nation and its people "[6, p.272]. Ho Chi Minh's ideals, goals, and reason are the interests of the Fatherland and the happiness of people. That has been proved by life with over 60 years of exciting revolutionary activities in Ho Chi Minh. Worried for the country, for the people, Ho Chi Minh had to sacrifice his family love and no moment to think for his own happiness. In a letter sent to his hometown when he learned that his brother had died, Ho Chi Minh wrote: "Upon hearing the news of brother's death, my heart was very sad. Because of heavy nation's work, the distant roads, when he was ill, I could not look after him, when he died, I could not take care. OMG! I feel guilty to my brother and pleaded for a generous selflessness for a son who sacrificed his love for his housework" [8, p.463]. Ho Chi Minh also had no family, no children. In a letter to Dr. Vu Dinh Tung's family (January 1947), Ho Chi Minh wrote: "I have no home, no wife, no children, Vietnam is my big family. Vietnamese seniors are my relatives. Vietnamese women are my sisters. I only have one desire to make my country independent, united and democratic. If I ever achieve that goal, I will return to be a tourist to visit the mountains, to read gardening books" [7, p.201]. Ho Chi Minh considered Vietnam to be his big family, all Vietnamese youths were descendants, considering the sadness and worry of each Vietnamese people as his own. On July 14, 1969, in Ho Chi Minh's interview with journalist Macta Rohat in Granma (Cuba), Ho Chi Minh said: "Each person and each family has its own suffering and includes its own ones of every person, every family, becomes my suffering" [10, p.674].

In the years of fighting, Ho Chi Minh committed a lot of suffering with the people, porridge of bamboo shoots, living in a cave. When Ho Chi Minh was President, Ho Chi Minh did not think for himself, Ho Chi Minh devoted his whole heart and mind to the People and to the nation. Ho Chi Minh was a person born for People, who lived among the people and wanted to return to the People at the end of his life, to build a small house, where there was green mountain and pure water, fishing and planting flowers, early afternoon making friends with old people gathering firewood, children, raising buffaloes, having nothing to do with fame and fortune. Ho Chi Minh always considered the People to be the owner, held the highest position, and he was just a loyal servant of the people, serving the People. When assigned by the National Assembly to assume the position of President of the Government, Ho Chi Minh considered it "mandated to be Chairman of the people by the people", taking on the President's responsibility to carry out the orders of the Fatherland and the People. Therefore, when "fellow countrymen let me go back, I would be happy to withdraw". Although busy with a lot of domestic and foreign 
affairs, coming to the people, coming to the masses, to study the people, asking the people, understanding the people, listening to the people, seeing the people doing it, to master the people, how people thought and did things meant the permanent needs of Ho Chi Minh. Ho Chi Minh went to the sports ground with the team, "put sticks on the ground to watch the battlefield", went to factories, construction sites, mines, farms, cooperatives, schools, hospitals. Ho Chi Minh went to daycare, kindergarten, went to the field, visited the houses of workers, ordinary officials, etc. In the last years of his life, Ho Chi Minh did not forget to monitor the daily life of the elite. People, discovered and rewarded more than 5,000 Ho Chi Minh badges for good people and good deeds. Love People in Ho Chi Minh was vast, vast but not general, abstract, not just words, empty theories, but very specific and sincere. Not only concerned with the problems of the people as a leader, the head of the country, Ho Chi Minh also devoted sincere and caring love as a grandfather and father in the family. As the late Prime Minister Pham Van Dong affirmed, the relationship between Ho Chi Minh and the nation was intimate, passionate, affection, solidarity, and affection. In Ho Chi Minh's heart, no one in the Vietnamese family has no place. People do not forget, do not miss anyone: young and old, boys and girls, ethnic minorities, overseas Vietnamese. Heartwarming stories telling the actions and gestures that seem small and simple but show Ho Chi Minh's sincerity, practicality, empathy with the people. Loving workers to sweep the streets late at night in winter, Ho Chi Minh reminded the people in charge of the labor wears to protect their health. When traveling abroad, Ho Chi Minh also bought winter trees with less deciduous leaves so that the workers would not have to waste the time and effort of sweeping the roads. Another story was told, in the summer of Hanoi capital in 1967, injured air defense soldiers on the roof of Ba Dinh Hall in the midst of the heat, Ho Chi Minh transferred all the savings earned by the newspapers. royalties to buy soft drinks for them ... Take hero Tran Thi Ly to visit the Presidential Palace garden, Ho Chi Minh avoided taking her on gravel roads because he knew that her feet stepping on gravel will affect the wounds on her head. . In the midst of nation and housework, Ho Chi Minh always understood and seeked to share the suffering of each and every people. Poet To Huu wrote:

$$
\text { "Uncle, why was your heart so big }
$$

Cover the whole river, the whole human life".

Ho Chi Minh had no personal interests other than the common good of the entire nation and no other happiness apart from the common happiness of the people, which was determined by the late Prime Minister Pham Van Dong: sacrificed and loyal to the nation, to the people. There was nothing personal, nothing of the country, of the people belong to him. The sovereignty of the nation, the daily benefit of the people, was his daily anxiety "[ 3 , p.33].

\section{Example of hardworking, economical, honesty, righteous, simple, modest of Ho Chi Minh}

Ho Chi Minh not only raised but also embodied the moral qualities: hardworking, economical, honesty, righteous, simple and modest. Throughout the life of his revolutionary activities, even as a kitchen assistant until becoming President - Ho Chi Minh always upheld a life of frugality, simplicity, regardless of fame, no desire for wealth, no desire luxury, not fond of luxurious etiquette. Throughout Ho Chi Minh's life, he worked hard, not wasting a minute and a second. Ho Chi Minh arranged scientific work to take advantage of the time to serve the country and the people. During the hard days of fighting, Ho Chi Minh worked very late. Ho Chi Minh manually typed documents. Ho Chi Minh read books, wrote books, wrote letters to the children, the elderly to encourage soldiers to fight on the front, letters to visit fellow citizens and international friends. Apart from directing the Vietnamese revolution, Ho Chi Minh also actively worked as manual workers such as planting vegetables and planting trees.

Ho Chi Minh did not let simple desires bothered him, though living in the capital of large countries, Ho Chi Minh's frivolous lavishness still kept a pure heart and a simple lifestyle. Or get used to austere life can not have another life, can not bear the lavish lifestyle or love the poor when he was President, Ho Chi Minh remained frugal, laborious, austere lifestyle. Ho Chi Minh said: "Everybody wants to eat well and wear nice clothes, but they want to be in the right time and in the right situation. While our people are in need, someone wants to eat well and eat well, so there is no morality" $[9$, p. 589]. Ho Chi Minh explained the need to practice "economical" because the country was still poor, still fighting, the people were deprived, therefore, they were not allowed to squander, to enjoy eating well and wearing nice clothes, "a coin, ie some sweat tears of the people. Therefore, we must strive to save. Waste is a crime" [7, p.241]. While living in the Northern region, Ho Chi Minh still maintained the same routine as in the war zone, eating rice with government employees with red rice, spinach, tofu, sometimes with sesame, some meat. After that, despite having a private kitchen, Ho Chi Minh's meals only had a savory dish, a vegetable dish and a soup. Appreciating the production results of people and respecting the waiters, Ho Chi Minh did not drop a single grain of rice, after finishing eating, the bowl was always clean and the remaining food was neatly arranged. Working on the grassroots level, in Ho Chi Minh city, bring sesame rice balls to avoid the grand reception which causes troubles and costs the people. The worn pencil Ho Chi Minh used to follow the news in the newspaper. Ho Chi Minh cars on business trips or visiting compatriots and soldiers are just ordinary cars. Ho Chi Minh did not use the air conditioner given by foreign officials working abroad, but offered to transfer it to the wounded and sick soldiers who were being treated at the nursing home even though Ho Chi Minh was at the time. 
The electrician's house was very hot. Clothes only a few sets, when the shirt was torn, Ho Chi Minh asked to patch it over and replace it. Rubber sandals made from old tires, Ho Chi Minh used to wear clothes that sewed many times. Ho Chi Minh refused to stay in the big, luxurious house of General Indochina Governor but in the electrician's small house, then moved to the stilt house. Ho Chi Minh dedicated that luxury home to the guests of the Communist Party of Vietnam and the government. The simple Ho Chi Minh house had only two small rooms, very simple furniture with a bed, a table, a chair, a bookshelf and a carpentry closet.

Despite contributing an excellent work to the country's culture, laying the foundations for modern Vietnamese revolutionary culture, being a prisoner of diaries, Ho Chi Minh was very humble and never admitted himself as a poet. Receiving letters and congratulatory gifts from the people, even though he was busy with hundreds of thousands of jobs, Ho Chi Minh wrote the reply himself, thankfully and thoughtfully, setting an example of very cultural and full moral behavior and respect for the people. Throughout his life of fighting incessantly, Ho Chi Minh refused all noble titles, medals and awards that the Communist Party of Vietnam, the State of Vietnam, the People of Vietnam, and international friends gave him. Until his dealth, there was no medal on Ho Chi Minh's chest.

\section{CONCLUSION}

In the construction of cultural life of the Vietnamese nation, Ho Chi Minh's thought and moral example have increasingly played an important role and position, contributing to building a solid spiritual foundation of the societythat are the basis for adjusting human behavior towards the true, the good and the beautiful. Vietnamese students are an additional source of highly qualified labor, playing a central role in the country's human resource development strategy. At the same time, they have the responsibility to soon bring the cause of the rich, strong country, democracy, justice and civilization of Vietnam to victory. To do so, it is necessary to take care of education for students, moral education for them is extremely important through Ho Chi Minh's moral example. Having done this work well, promoting the strong resources of the young intellectuals so that they can become qualified and capable people, meeting the requirements of national development and fulfilling the great responsibility that history, people and nation gave to them.

\section{REFERENCES}

1. Le Thi Van Anh (2016), Education of Ho Chi Minh's moral education for students of universities and colleges in teaching Ho Chi Minh Thought, Publishing House. National politics.

2. Thanh Duy (1996), Ho Chi Minh's thought about morality, Publishing House. National politics.

3. Pham Van Dong (1975), Ho Chi Minh President, uintessence of the nation, conscience of the times, Publishing house. The Truth.

4. Manh Ha collected and edited (2007), Following Uncle Ho's moral Example, Publishing House. Encyclopedic dictionary.

5. Tran Viet Hoan (2017), Uncle Ho's morality, an example for all generations, Publishing house. National politics, The Truth.

6. Ho Chi Minh (2011), Full volume, volume 4, Publishing house. National politics, Hanoi.

7. Ho Chi Minh (2011), Full volume, volume 5, Publishing house. National politics, Hanoi.

8. Ho Chi Minh (2011), Full volume, volume 6, Publishing house. National politics, Hanoi.

9. Ho Chi Minh (2011), Full volume, volume 10, Publishing house. National politics, Hanoi.

10. Ho Chi Minh (2011), Full volume, volume 15, Publishing house. National politics, Hanoi.

11. Song Thanh (2016), Uncle Ho - Bright Moral Example, Publishing house. National politics, The Truth. 